\title{
Mulching and Fertilization Effects on Weed Dynamics under Conservation Agriculture-Based Maize Cropping in Zimbabwe ${ }^{\dagger}$
}

\section{Florence Mtambanengwe ${ }^{1, *}$, Hatirarami Nezomba ${ }^{1}$, Tonny Tauro ${ }^{2}$, Christopher Chagumaira ${ }^{1}$, Muneta G. Manzeke ${ }^{1}$ and Paul Mapfumo ${ }^{1}$}

1 The Soil Fertility Consortium for Southern Africa (SOFECSA), Department of Soil Science \& Agricultural Engineering, University of Zimbabwe, P.O. Box MP 167, Mount Pleasant, Harare 00263, Zimbabwe; E-Mails: hatienez@yahoo.co.uk (H.N.); chris.chagumaira@gmail.com (C.C.); manzekegrace@gmail.com (M.G.M.); p.mapfumo@agric.uz.ac.zw (P.M.)

2 Marondera College of Agricultural Science \& Technology, c/o University of Zimbabwe, P.O. Box MP 167, Mt Pleasant, Harare 00263, Zimbabwe; E-Mail: phirilani2@yahoo.co.uk

$\dagger$ Oral presentation at the 1st Africa Congress on Conservation Agriculture, Session: Congress Sub-Theme Keynote Papers, Lusaka, Zambia, 18-21 March 2014.

* Author to whom correspondence should be addressed; E-Mail: fmtamba@agric.uz.ac.zw or fmtamba@gmail.com; Tel.: +263-4-303-211 (ext. 15530).

Academic Editors: Amir Kassam, Saidi Mkomwa and Yu-Pin Lin

Received: 9 June 2015 / Accepted: 11 August 2015 / Published: 25 August 2015

\begin{abstract}
A two-year study was conducted to assess how mulch influences weed dynamics following imposition of different fertilization treatments under three crop establishment options: (i) conventional; (ii) ripping; and (iii) basin, in a two-year maize-legume rotation. Eight treatments were imposed within each crop establishment option and received maize stover mulch applied at $0 \%$ or $30 \%$ cover before planting maize (Zea mays) or cowpea (Vigna unguiculata) as test crops. Maize received nitrogen $(\mathrm{N})$ at 35,90 , or $120 \mathrm{~kg} \cdot \mathrm{ha}^{-1}$ and phosphorus (P) at 14 or $26 \mathrm{~kg} \cdot \mathrm{ha}^{-1}$ applied alone or in combination with 4 or $7 \mathrm{t}$ cattle manure $\cdot \mathrm{ha}^{-1}$, while cowpea received 8 or $17 \mathrm{~N} \cdot \mathrm{kg} \cdot \mathrm{ha}^{-1}$ and similar $\mathrm{P}$ rates to maize. Results indicated that both weed biomass and diversity were influenced more by fertilization than method of crop establishment. On treatments under high fertilizer application rates, or previously planted to cowpea weed biomass ranged between 220 and $400 \mathrm{~g} \cdot \mathrm{m}^{-2}$ under mulch and $370-510 \mathrm{~g} \cdot \mathrm{m}^{-2}$ (no mulch). Here species richness ranged
\end{abstract}


between 7-16 and was dominated by dicotyledons. This was in contrast to biomass ranges of $75-200 \mathrm{~g} \cdot \mathrm{m}^{-2}$ in the low fertilized and control plots, where only one or two grass types dominated. Overall, weed densities were $6 \%$ to $51 \%$ higher under conventional tillage compared to the two conservation agriculture (CA) options, although the data indicated that mulch significantly $(p<0.05)$ depressed weed density by up to $70 \%$. We concluded that mulching could be a potential mechanism for reducing weeding labor costs for smallholders and the general environmental and health concerns associated with the use of herbicides in CA systems.

Keywords: basins; conventional tillage; ripping; Shannon Weiner index; soil fertility; weed density; weed diversity

\section{Introduction}

Over the last decade, the United Nations' Food and Agriculture Organization (FAO) has been promoting conservation agriculture (CA) among smallholder farmers in southern Africa including Zimbabwe [1]. Conceptually, CA practices center around minimum soil disturbance, which is accompanied by mulching, and crop diversification, either through rotations or intercrops [2,3]. Promotion of CA was meant to address the many challenges farmers face in their quest to produce food for household subsistence: farming on unproductive soil, accelerated land degradation, and the high costs of input, labor, and associated production costs. However, in the majority of cases, the reduction in intensity of land preparation brought its own problems to the farming community including low productivity as a result of poor crop seed germination and high weed infestation. Advancements in CA research have resulted in the development of a range of machinery to address labor concerns in land preparation, promotion of crop rotation with beneficial crops such as legumes, and use of herbicides for weed control [4]. This has allowed farmers to reduce and even eliminate time allocated to land preparation activities, and at the same time maintain or improve yield levels.

One of the most important constraints in smallholder farming is the labor associated with weeding. Traditionally, farmers in Zimbabwe have used winter plowing as a weed control and moisture conservation measure [5]. During the growing season, weeds have also been controlled mechanically using animal-drawn cultivators and/or hand-hoes. The introduction of CA has therefore come with new demands for weed control. Research on challenges to CA adoption has identified weed proliferation as one of the key factors hindering its widespread uptake among smallholder farming communities of Zimbabwe. It can be argued that under smallholder farming, weed control ranks top when it comes to demands on labor. The cost of labor required to address this is often beyond the reach of many farming households [6,7]. Although herbicides have often been advocated for control of weeds under CA systems, there is need for research, extension, and development partners to continue to build the capacity of farmers on their use in CA management.

A common observation from the Soil Fertility Consortium for Southern Africa (SOFECSA) work under a project entitled Agroecology-Based Aggradation Conservation Agriculture (ABACO) in both Mozambique and Zimbabwe indicate that there is a general lack of technical know-how concerning 
herbicide use among smallholders [8]. Smallholder farmers failed to separate the different herbicide groups, where some pre-emergence have been used after crop establishment, and in other cases, poor knowledge of some specific post-emergence herbicides have resulted in total loss of the staple maize crop. Low adoption of technologies, such as herbicide use, may also be linked to the general low purchasing power among this target group [8], who often opt for hand-weeding using family labor, in order to reduce costs. These preliminary studies have also shown that in most CA extension in semi-arid zones including Zimbabwe, emphasis is often on reducing water loss and moderating soil temperatures [9], with little mention on weed suppression. However, it has remained unclear how different components of CA influence weed dynamics, particularly under the dominant maize-based cropping systems of Zimbabwe. Limited studies to date have failed to give conclusive results on the dynamics of weed density and diversity under mulching and different crop establishment options when fertilization is introduced [10-12].

This paper therefore examines the potential of mulching, one of the three principles of CA, to address the weed problem farmers face in their crop production systems. The FAO defines mulch as "material which is applied to the soil surface in order to reduce water loss, suppress weeds, reduce fruit splashing, modify soil temperatures, and generally improve crop productivity" [13]. Under smallholder farming, mulching materials often include, but are not restricted to, crop (mostly cereal) residues and grasses harvested from outside the field environment. This paper looks at the potential role mulch plays in weed suppression, following different soil fertility treatments under three crop establishment options in a semi-arid area in Zimbabwe.

\section{Materials and Methods}

\subsection{Study Site Description}

The study was conducted at Domboshawa Training Centre $\left(17^{\circ} 35^{\prime} \mathrm{S}, 31^{\circ} 14^{\prime} \mathrm{E}\right), 30 \mathrm{~km}$ north of the capital city of Zimbabwe, Harare. Domboshawa is in Zimbabwe's agro-ecological region (natural region [NR]) IIA (Figure 1) and receives $>800 \mathrm{~mm}$ of rainfall annually in a unimodal season between November and March. Agro-zonation in Zimbabwe is primarily based on the average rainfall amounts a region receives between November and March, where NR I, in the eastern part of the country, receives the highest amounts of $>1000 \mathrm{~mm} \cdot$ annum $^{-1}$, followed by NR IIA and $\mathrm{B}$, receiving between 750 and $1000 \mathrm{~mm} \cdot$ annum $^{-1}$, with the least amount of rainfall being received in NR V $\left(<450 \mathrm{~mm} \cdot\right.$ annum $\left.^{-1}\right)$, in the northwest and southern parts of the country (Figure 1) [14]. The soils at Domboshawa are granite-derived sandy clay loams broadly falling under Lixisols [15], have inherent deficiencies of nitrogen $(\mathrm{N})$ and phosphorus $(\mathrm{P})$, and are characterized by low organic matter contents.

\subsection{Background to the Study}

The Soil Fertility Consortium for Southern Africa (SOFECSA), hosted by the University of Zimbabwe, partnered in a multi-country project entitled "ABACO — Targeting innovations to combat soil degradation and food insecurity in semi-arid Africa," led by the African Conservation Tillage Network (ACT) (http://www.act-africa.org/). The overall objective of ABACO (http://abaco.act-africa.org) was to reduce the vulnerability of smallholder farmers to climatic variability by building capacity through co-innovation platforms to design, evaluate, and implement targeted technological options for and 
mechanisms to promote adoption of CA based on agro-ecology principles to combat land degradation and food insecurity in semi-arid regions of Africa [16]. The SOFECSA work under ABACO focused on soil rehabilitation and integrated soil fertility management (ISFM), testing CA options for rehabilitating degraded soils.

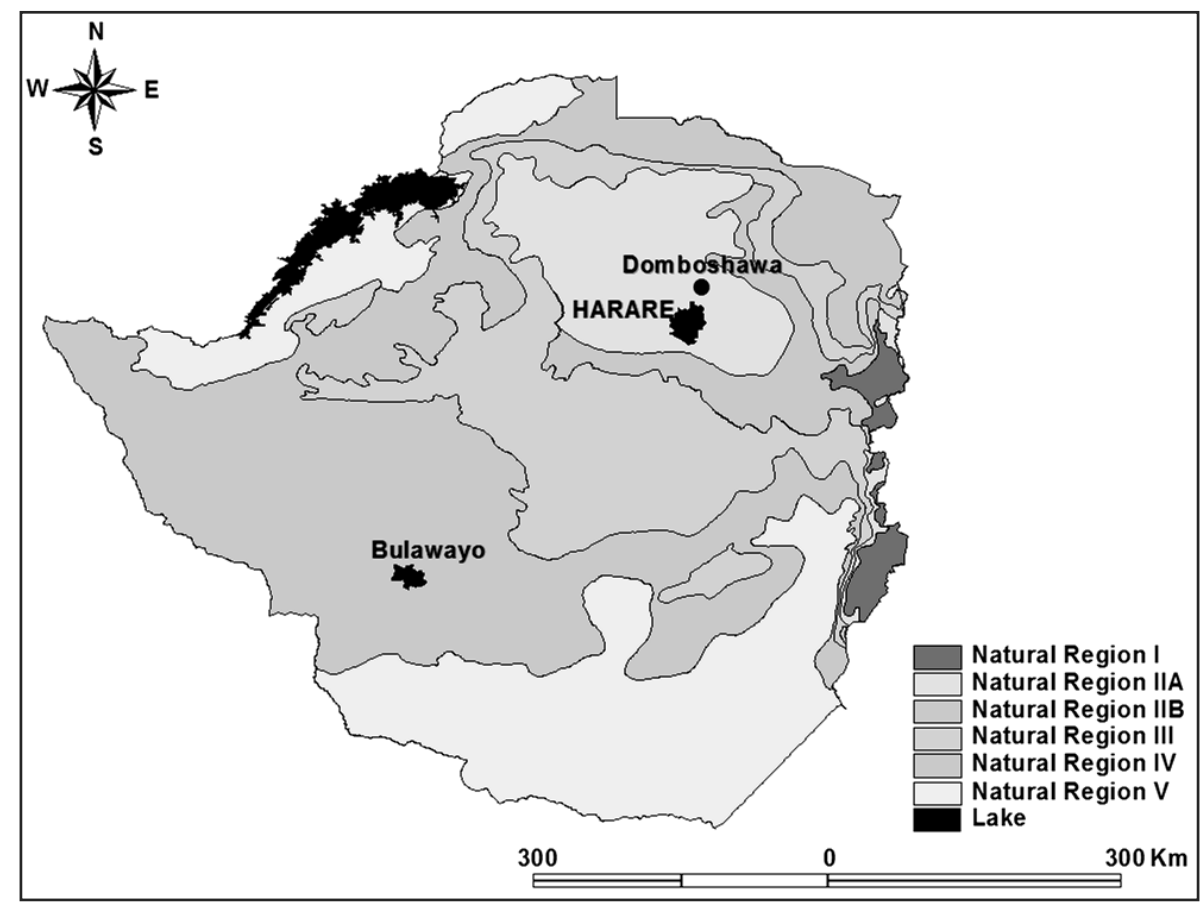

Figure 1. A map of Zimbabwe showing the study site Domboshawa and the country's agro-ecological regions.

\subsection{Experimental Layout, Treatments, and Agronomic Management}

The study was conducted over two years between 2011 and 2013. In the first year, three crop establishment options were introduced before the onset of the rains in October 2011 to a field previously grown with maize (Zea mays L.). The crop establishment options tested over two seasons (2011/12 and 2012/13) were:

(i) Conventional (tillage with conventional ox-drawn moldboard plow)

(ii) Ripping (using ripper tine)

(iii) Planting basins (basins-basin size $=15 \mathrm{~cm} \times 15 \mathrm{~cm} \times 15 \mathrm{~cm}$ )

Within each crop establishment option, eight treatments were imposed, each planted with either maize, the staple cereal of Zimbabwe, or a grain legume, in this case cowpea (Vigna unguiculata L. [Walp]) was grown. In addition, nitrogen (N) and phosphorus (P) were used as mineral fertilizer options applied at a high (90 or $120 \mathrm{~kg} \cdot \mathrm{N} \cdot \mathrm{ha}^{-1}$ and $26 \mathrm{~kg} \cdot \mathrm{P} \cdot \mathrm{ha}^{-1}$ ) or low $\left(17\right.$ or $35 \mathrm{~kg} \cdot \mathrm{N} \cdot \mathrm{ha} \mathrm{a}^{-1}$ and $14 \mathrm{~kg} \cdot \mathrm{P} \cdot \mathrm{ha}^{-1}$ ) rates, while cattle manure was used as the organic fertilizer option, also either at high $\left(7 \mathrm{t} \cdot \mathrm{ha}^{-1}\right)$ or low $\left(4 \mathrm{t} \cdot \mathrm{ha}^{-1}\right)$ rates. The quality of manure was $30 \% \mathrm{C}, 1.1 \% \mathrm{~N}, 0.24 \% \mathrm{P}, 2.9 \%$ lignin, and $0.2 \%$ polyphenols. The treatments are as described in Table 1 .

The experimental layout was a complete randomized block design with three replicates per crop establishment option (Figure 2). The plot size for each treatment of the eight treatments was $28 \mathrm{~m}^{2}$. 
A short-to-medium maturity maize (SC 513) variety was planted in $0.90 \mathrm{~m}$ (inter) $\times 0.30 \mathrm{~m}$ (intra) rows, with two seeds per station and subsequently thinned to one at two weeks after emergence (WAE) in the conventional and ripping crop establishment options, while three seeds were planted to each basin, and eventually thinned to two at two WAE to achieve plant population of approximately 37,000 plants $\mathrm{ha}^{-1}$ (see Table 2). Cowpea was planted using the recommended spacing of $0.45 \mathrm{~m}$ inter-row and $0.15 \mathrm{~m}$ within rows across the crop establishment options.

Prior to trial establishment, the field was treated with a herbicide, glyphosate, ( $N$-(phosphonomethyl)glycine) $\left(\mathrm{C}_{3} \mathrm{H}_{8} \mathrm{NO}_{5} \mathrm{P}\right)$, a broad-spectrum systemic herbicide to control weeds. Mulch in the form of whole maize stover from the previous season was then applied to one half of each of the eight treatment plots (Figure 2) in both season 1 (2011/12) and season 2 (2012/13) to maintain a $30 \%$ ground cover at the beginning of the cropping season. In the second season, treatments $1-6$ were rotated, giving four maize treatments and four cowpea treatments, while mulching was maintained in the same subplot as in season 1 (Figure 2).

Table 1. Treatments imposed under three crop establishment options over two seasons at Domboshawa, Zimbabwe showing maize-cowpea rotations.

\begin{tabular}{|c|c|c|c|c|}
\hline \multirow{2}{*}{ Plot No. } & \multicolumn{2}{|r|}{ Season 1 (2011-2012) Treatments } & \multicolumn{2}{|c|}{ Season 2 (2012-2013) Treatments } \\
\hline & Test Crop & Fertilizer Rate and Type & Test Crop & Fertilizer Rate and Type \\
\hline 1 & Maize & $\begin{array}{c}\text { High rate } \\
\left(120 \mathrm{~kg} \cdot \mathrm{N} \cdot \mathrm{ha}^{-1} ; 26 \mathrm{~kg} \cdot \mathrm{P} \cdot \mathrm{ha}^{-1}\right)\end{array}$ & Cowpea & $\begin{array}{c}\text { high rate } \\
\left(17 \mathrm{~kg} \cdot \mathrm{N} \cdot \mathrm{ha}^{-1} ; 26 \mathrm{~kg} \cdot \mathrm{P} \cdot \mathrm{ha}^{-1}\right)\end{array}$ \\
\hline 2 & Cowpea & $\begin{array}{c}\text { High rate } \\
\left(17 \mathrm{~kg} \cdot \mathrm{N} \cdot \mathrm{ha}^{-1} ; 26 \mathrm{~kg} \cdot \mathrm{P} \cdot \mathrm{ha}^{-1}\right)\end{array}$ & Maize & $\begin{array}{c}\text { high rate } \\
\left(120 \mathrm{~kg} \cdot \mathrm{N} \cdot \mathrm{ha}^{-1} ; 26 \mathrm{~kg} \cdot \mathrm{P} \cdot \mathrm{ha}^{-1}\right)\end{array}$ \\
\hline 3 & Maize & $\begin{array}{c}\text { Low rate } \\
\left(35 \mathrm{~kg} \cdot \mathrm{N} \cdot \mathrm{ha}^{-1} ; 14 \mathrm{~kg} \cdot \mathrm{P} \cdot \mathrm{ha}^{-1}\right)\end{array}$ & Cowpea & $\begin{array}{c}\text { low rate } \\
\left(8 \mathrm{~kg} \cdot \mathrm{N} \cdot \mathrm{ha}^{-1} ; 14 \mathrm{~kg} \cdot \mathrm{P} \cdot \mathrm{ha}^{-1}\right)\end{array}$ \\
\hline 4 & Cowpea & $\begin{array}{c}\text { Low rate } \\
\left(8 \mathrm{~kg} \cdot \mathrm{N} \cdot \mathrm{ha}^{-1} ; 14 \mathrm{~kg} \cdot \mathrm{P} \cdot \mathrm{ha}^{-1}\right)\end{array}$ & Maize & $\begin{array}{c}\text { low rate } \\
\left(35 \mathrm{~kg} \mathrm{~N} \cdot \mathrm{ha}^{-1} ; 14 \mathrm{~kg} \cdot \mathrm{P} \cdot \mathrm{ha}^{-1}\right)\end{array}$ \\
\hline 5 & Maize & 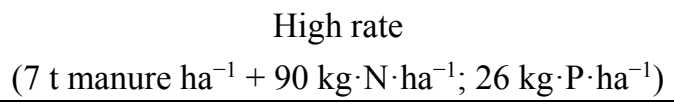 & Cowpea & $\begin{array}{l}\text { Residual fertility } \\
\text { (high fertilizer rate) }\end{array}$ \\
\hline 6 & Maize & $\begin{array}{c}\text { Low rate } \\
\left(4 \mathrm{t} \mathrm{manure} \mathrm{ha}{ }^{-1}+35 \mathrm{~kg} \cdot \mathrm{N} \cdot \mathrm{ha}^{-1} ; 14 \mathrm{~kg} \cdot \mathrm{P} \cdot \mathrm{ha}^{-1}\right)\end{array}$ & Cowpea & $\begin{array}{l}\text { Residual fertility } \\
\text { (low fertilizer rate) }\end{array}$ \\
\hline 7 & Maize & Control-no fertilizer & Maize & Control-no fertilizer \\
\hline 8 & Maize & $\begin{array}{c}\text { high rate } \\
\left(120 \mathrm{~kg} \cdot \mathrm{N} \cdot \mathrm{ha}^{-1} ; 26 \mathrm{~kg} \cdot \mathrm{P} \cdot \mathrm{ha}^{-1}\right)\end{array}$ & Maize & $\begin{array}{c}\text { high rate } \\
\left(120 \mathrm{~kg} \cdot \mathrm{N} \cdot \mathrm{ha}^{-1} ; 26 \mathrm{~kg} \cdot \mathrm{P} \cdot \mathrm{ha}^{-1}\right)\end{array}$ \\
\hline
\end{tabular}




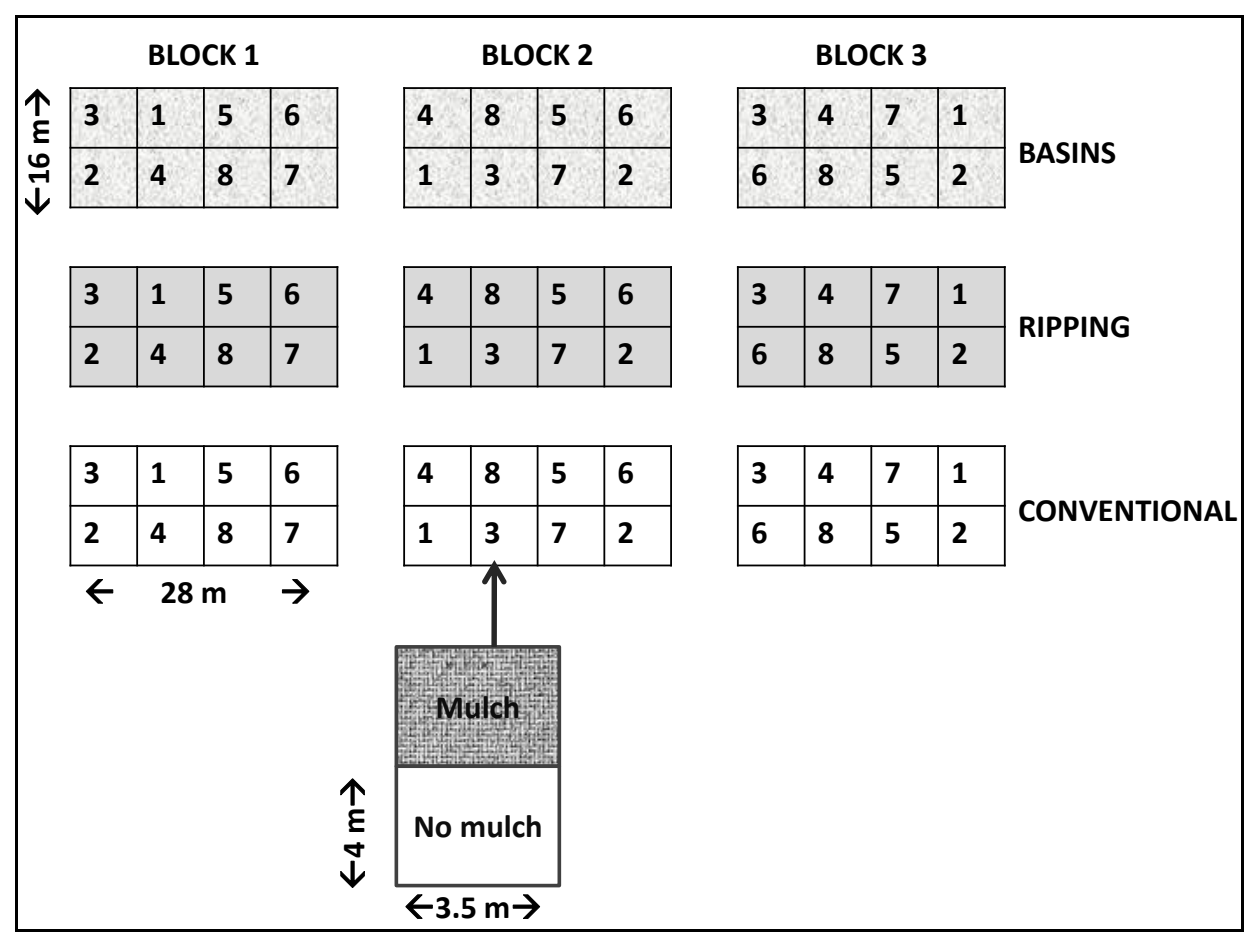

Figure 2. Experimental layout for the field experiments at Domboshawa Training Centre, Zimbabwe, with three crop establishment options of conventional tillage, ripping and basins. 1-8 indicate the main plots as follows: 1: Fertilized maize $\left(120 \mathrm{~kg} \cdot \mathrm{N} \cdot \mathrm{ha}^{-1} ; 26 \mathrm{~kg} \cdot \mathrm{P} \cdot \mathrm{ha}^{-1}\right)$; 2: Fertilized cowpea $\left(17 \mathrm{~kg} \cdot \mathrm{N} \cdot \mathrm{ha}^{-1} ; 26 \mathrm{~kg} \cdot \mathrm{P} \cdot \mathrm{ha}^{-1}\right) ; 3$ : Fertilized maize $\left(35 \mathrm{~kg} \cdot \mathrm{N} \cdot \mathrm{ha}^{-1}\right.$; $\left.14 \mathrm{~kg} \cdot \mathrm{P} \cdot \mathrm{ha}^{-1}\right)$; 4: Fertilized cowpea $\left(8 \mathrm{~kg} \cdot \mathrm{N} \cdot \mathrm{ha}^{-1} ; 14 \mathrm{~kg} \cdot \mathrm{P} \cdot \mathrm{ha}^{-1}\right) ; 5:$ Fertilized maize (7 t manure $\left.+90 \mathrm{~kg} \cdot \mathrm{N} \cdot \mathrm{ha}^{-1} ; 26 \mathrm{~kg} \cdot \mathrm{P} \cdot \mathrm{ha}^{-1}\right) ; 6$ : Fertilized maize (4 t manure $\mathrm{ha}^{-1}+$ $35 \mathrm{~kg} \cdot \mathrm{N} \cdot \mathrm{ha}^{-1} ; 14 \mathrm{~kg} \cdot \mathrm{P} \cdot \mathrm{ha}^{-1}$ ); 7: Unfertilized maize (Control); and 8: Fertilized maize $\left(120 \mathrm{~kg} \cdot \mathrm{N} \cdot \mathrm{ha}^{-1} ; 26 \mathrm{~kg} \cdot \mathrm{P} \cdot \mathrm{ha}^{-1}\right)$. Each of the eight main plots (1-8) per block per crop establishment option was further sub-divided into "mulched" and "no mulch." Please note: during the second season, the test crop was rotated except for the two controls (treatments 7 and 8).

Table 2. Agronomic management of maize and cowpea under conventional tillage, ripping, and planting basin options in season two (2012/13) at Domboshawa in Zimbabwe.

\begin{tabular}{cccc}
\hline \multirow{2}{*}{ Crop Type and Management } & \multicolumn{3}{c}{ Crop Establishment Option } \\
\cline { 2 - 4 } MAIZE (SC 513 early-medium maturity) & & Ripping & Basins \\
Land preparation & 28 November 2012 & 3 November 2012 & 3 November 2012 \\
Mulching @30\% cover & 28 November 2012 & 28 November 2012 & 28 November 2012 \\
Planting date & 29 November 2012 & 29 November 2012 & 29 November 2012 \\
Seeds per station & 2 & 2 & 3 \\
Thinning & 13 December 2012 & 13 December 2012 & 13 December 2012 \\
Thinned to: & 1 & 1 & 2 \\
\hline
\end{tabular}


Table 2. Cont.

\begin{tabular}{|c|c|c|c|}
\hline \multirow{2}{*}{ Crop Type and Management } & \multicolumn{3}{|c|}{ Crop Establishment Option } \\
\hline & Conventional & Ripping & Basins \\
\hline Target population & \multicolumn{3}{|c|}{37,000 plants ha ${ }^{-1}$} \\
\hline First fertilizer application & \multicolumn{3}{|c|}{ Basal at planting } \\
\hline Manure application & \multicolumn{3}{|c|}{ At planting } \\
\hline Weeding & \multicolumn{3}{|c|}{6 weeks after crop emergence } \\
\hline Second fertilizer application & \multicolumn{3}{|c|}{ Top-dressing 6 weeks after crop emergence } \\
\hline Pesticide application & \multicolumn{3}{|c|}{$\begin{array}{l}\text { Kombat (2.5\% Carbaryl) at } 3-4 \mathrm{~kg} \cdot \mathrm{ha}^{-1} \text { for maize stalk borer } \\
\text { (Busseola fusca) at } 6 \text { weeks after emergence }\end{array}$} \\
\hline Harvesting & \multicolumn{3}{|c|}{28 April 2013} \\
\hline \multicolumn{4}{|l|}{ COWPEA (CBC 2- erect variety) } \\
\hline Land preparation & 28 November 2012 & 3 November 2012 & 3 November 2012 \\
\hline Mulching@30\% cover & 28 November 2012 & 28 November 2012 & 28 November 2012 \\
\hline Planting date & 29 November 2012 & 29 November 2012 & 29 November 2012 \\
\hline Seeds per station & 2 & 2 & 3 \\
\hline Spacing & \multicolumn{3}{|c|}{$0.45 \mathrm{~m}$ between rows and $0.15 \mathrm{~m}$ within rows } \\
\hline Fertilizer application & \multicolumn{3}{|c|}{ Basal at planting } \\
\hline Manure application & \multicolumn{3}{|c|}{ At planting } \\
\hline Weeding & \multicolumn{3}{|c|}{6 weeks after crop emergence } \\
\hline \multirow[t]{2}{*}{ Pesticide application } & \multicolumn{3}{|c|}{$\begin{array}{c}\text { Dimethoate at } 2 \mathrm{~mL} \text { per liter of water at } 30 \text { days after } \\
\text { emergence for aphids }\end{array}$} \\
\hline & \multicolumn{3}{|c|}{$\begin{array}{l}\text { Dimethoate at } 60 \text { days after emergence } 2 \mathrm{~mL} \text { per liter of water at } \\
30 \text { days after emergence for aphids }\end{array}$} \\
\hline Harvesting & \multicolumn{3}{|c|}{$\begin{array}{l}\text { First harvesting beginning of March till all the pods were harvested } \\
\text { end of April } 2013\end{array}$} \\
\hline
\end{tabular}

\subsection{Weed Data Collection and Analysis}

Weed biomass quantification was conducted during the second season (2012/13). Weeds were allowed to grow till the test crop was about six weeks old. Using the quadrat method $[17,18]$, weeds were sampled at six weeks after crop emergence, before clean weeding and top-dressing fertilizer application to maize (see Table 2). The quadrats, measuring $0.5 \times 0.5 \mathrm{~m}^{2}$, were randomly thrown three-times across the target subplot and all weed biomass falling within each quadrat determined, before sub-sampling for species identification. An individual plant count was made for some monocotyledons (monocots) and broadleaved dicotyledons (dicots), while perennial grasses were subjected to stem counts. Most of the weed species were identified in situ, while unknown species were collected, pressed, and taken to the National Herbarium in Harare for identification.

Species dominance was determined through manual counting of the different species within each quadrat and results multiplied by 4 to get estimates per $\mathrm{m}^{2}$ per subplot. To homogenize variances, the weed density data under the mulched and non-mulched treatment with the three crop establishment options was square-root transformed $\operatorname{SQRT}(x)$, as described by [19]. The data were subjected to analysis of variance using GenStat 14th edition [20]. Treatment means were separated using standard error of the differences of means (SED) at $p<0.05$. Species diversity was determined by the 
Shannon-Wiener Index [21]. The Shannon-Wiener Diversity Index, $H$, was calculated using the following equations:

$$
\begin{gathered}
p_{i}=\frac{n i}{N} \\
H^{\prime}=-\sum_{i=1}^{S} p_{i}(\ln (p i)),
\end{gathered}
$$

where: $\mathrm{n}_{i}=$ number of individuals of species " $i$ "; $N=$ Total number of individuals of all species; $p_{i}=$ relative abundance of species " $i$ " (see Equation (1)); $S=$ total number of species; and $H^{\prime}=$ the Shannon Diversity Index (see Equation (2)).

\section{Results and Discussion}

\subsection{Weed Population Dynamics under Different Crop Establishment Options}

A total of 16 weed species were identified from the CA plots in Domboshawa. Of these, at least 11 were dicots comprising herbaceous annuals and perennials, while the remainder were monocots, the common grasses (Table 3). However, at the time of sampling, during season two, there were no apparent differences in the relative dominance of the different weed species across the three crop establishment options. The weed flora across all three crop establishment options was dominated by the herbaceous annual, Galinsoga parviflora (the gallant soldier), and the perennial herbaceous graminoids Cynodon nlemfuensis (star grass) and C. dactylon (couch grass), which constituted $>50 \%$ of total weed populations (Table 3). This was followed by Richardia scabra (rough Mexican clover) making up between $20 \%$ and $50 \%$, and Acanthospermum hispidum (bristly starbur) at 20\%-30\% of total weed species.

Table 3. Weed flora identified at the conservation agriculture field at Domboshawa in Zimbabwe.

\begin{tabular}{ccc}
\hline Species & Common Name & Relative Dominance Overall (\%) \\
\hline Herbaceous weeds & & \\
Galinsoga parviflora Cav. & Gallant soldier & $35-72$ \\
Richardia scabra L. & Mexican clover & $20-50$ \\
Acanthospermum hispidum DC & Bristly starbur & $20-30$ \\
Bidens pilosa L. & Cobbler's pegs & $10-15$ \\
Commelina benghalensis L. & Tropical spiderwort & $<10$ \\
Crotalaria cylindrostachys Welw. Ex Baker & Crotalaria & $<10$ \\
Macrotyloma daltonii (Webb) Verdc. & Macrotyloma & $<10$ \\
Amaranthus thunbergii Moq. & Thunberg's amaranth & $<5$ \\
Leucas martinicensis (Jacq.) R.Br. & Whitewort & $<5$ \\
Hibiscus cannabinus L. & Java jute & $<2$ \\
Nicandra physalodes (L.) Gaertn. & Shoo-fly plant & $<2$ \\
\hline Grasses & & \\
Cynodon nlemfuensis Vanderyst (Bogdan) & Stargrass & $50-100$ \\
Cynodon dactylon (L.) Pers & Couch grass & $50-80$ \\
Eleusine indica (L) Gaertn. & Wiregrass & $<20$ \\
Cyperus esculentus L. & Yellow nutsedge & $<2$ \\
Bulbostylis hispidula (Vahl) R.W. Haines & Hispidula & $<2$ \\
\hline
\end{tabular}


Other plants less dominant but prevalent across the three crop establishment options included the herbaceous annual monocot Commelina benghalensis, the grass Elusine indica, and the annual dicots Bidens pilosa, Crotalaria cylindrostachys, and Macrotyloma daltonii (Table 3). While changes in tillage practices and management have been known to lead to shifts in weed species composition [7,11], the similarities in species composition across the three crop establishment options observed in this study suggest that this is not the case in the short term. Differences were only observed when it came to weed densities, which were highest under conventional tillage (120-270 plants $\left.\cdot \mathrm{m}^{-2}\right)$ compared to 70-230 plants $\cdot \mathrm{m}^{-2}$ under planting basins and 35-220 plants $\mathrm{m}^{-2}$ under ripping (Figure 3). The effect of conventional tillage on weed emergence in this study agrees with other findings where annual broadleaf emergence was greater in tilled plots $(11,12)$ compared with planting basins and ripping. This suggests that the moldboard plow buries some seeds at depth when inverting the soil, and most of these seeds do not lose their viability and will germinate when the soil is disturbed again and are brought to or near the surface.

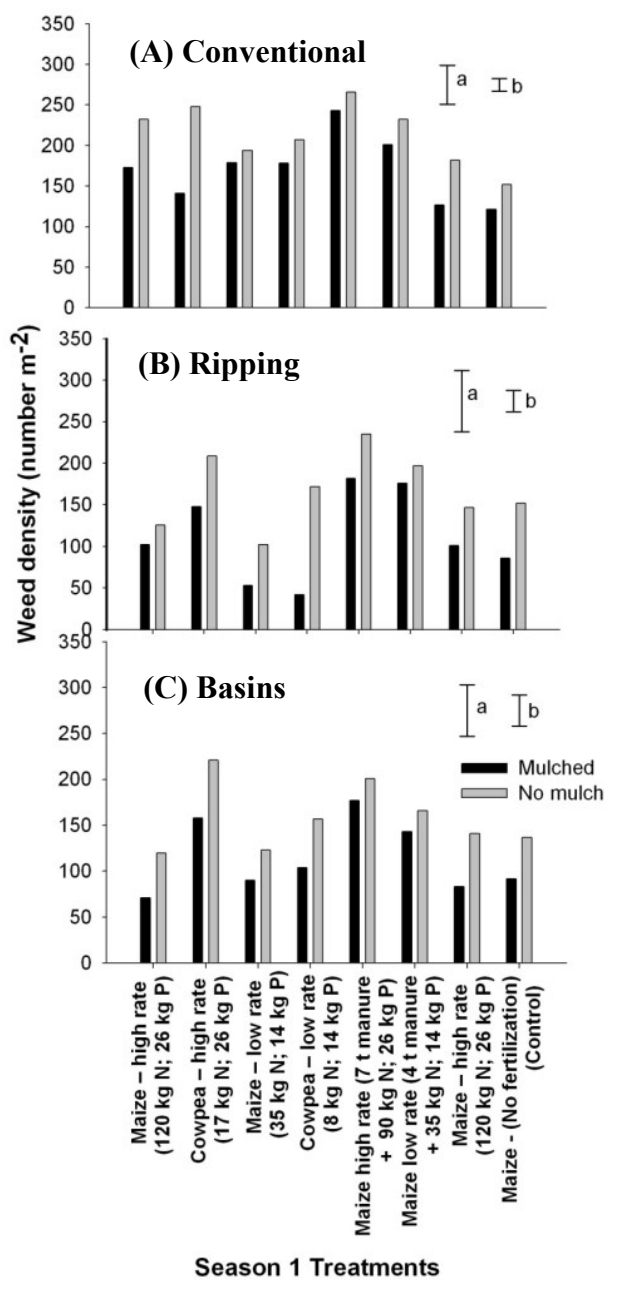

Figure 3. Residual effects of different fertility treatments and mulching on total weed populations under three crop establishment options (A) Conventional; (B) Ripping; and (C) Basins, at Domboshawa, Zimbabwe. Error bars indicate standard error of the mean (SEM), where bar (a) compares across treatments, and (b) compares within treatment (mulch versus no mulch). 


\subsection{Fertility Effects on Weed Flora}

Analysis of the fertilization treatment effects on weed species richness, biomass, and density within each crop establishment option indicated high variability across treatments. Two scenarios were, however, apparent: (i) where there was a high fertilizer application rate $\left(90 \mathrm{~kg} \cdot \mathrm{N} \cdot \mathrm{ha}^{-1} ; 26 \mathrm{~kg} \cdot \mathrm{P} \cdot \mathrm{ha}^{-1}\right.$; $7 \mathrm{t}$ manure $\cdot \mathrm{ha}^{-1}$ ), or in plots previously planted with cowpea, the dicots, G. parviflora and B. pilosa dominated, and mean weed biomass was highest, ranging between $220-400 \mathrm{~g} \cdot \mathrm{m}^{-2}$ under mulch and between $370-510 \mathrm{~g} \cdot \mathrm{m}^{-2}$ where no mulch was applied (Table 3 ). Weed densities also followed the same trend, being highest in plots with high fertilizer application rates and residual effects of cowpea. Individual weed counts under these treatments were as high as 250 plants $\mathrm{m}^{-2}$ (Figure 3). (ii) Where there was low fertilizer application rates, or in maize monocrop, the herbaceous weed, $R$. scabra and/or one of the two grass species Cynodon nlemfuensis (star grass) and C. dactylon dominated. On such plots, biomass was generally low and ranged between 75 and $200 \mathrm{~g} \cdot \mathrm{m}^{-2}$, while weed counts were generally $<150 \mathrm{~m}^{-2}$ under basins and ripping, but comparable to others under conventional tillage (Figure 3). This response of weed flora to fertility treatments was probably triggered by nutrient availability in soils, which already had a low nutrient capital, a characteristic of granite-derived sands that typifies the Domboshawa study site. However, the weed biomass results may suggest that intensive fertility management such as application of high fertilizer (organic or mineral) amounts could promote weed infestation and subsequent management on smallholder farms in similar agro-ecologies.

Under cattle manure-based treatments, weeds were denser under conventional tillage compared to basins and ripping (Figure 3). This could partly be explained by the methods of manure application under the different crop establishment systems, where in conventional tillage, manure was broadcast in contrast to banding (under ripping) and spot application (planting basins). Studies have shown that manure from free range cattle may often contain considerable numbers of germinable weed seeds from grazing $[22,23]$. The passage of these seed though the animal gut may actually stimulate the weed seeds to germinate [24]. The dicots Amaranthus thunbergii and A. hispidium, together with the grasses E. indica, C. dactylon, and C. nlemfuensis, were typical weeds linked with manure application (observations also made by [25]).

On the other hand, annual weeds such as $R$. scabra and $C$. dactylon that are known to persist in infertile soils $[6,22]$ were seen to dominate low fertility conditions and evidently out-compete other poor competitors. This was apparent particularly in the unfertilized control and other treatments previously subjected to low fertilization across all crop establishment options where there was a $100 \%$ cover of Cynodon spp. While the genus Cynodon is known to adapt to a wide range of soils, it is also an effective colonizer due to its ability to compete for soil, water, nutrients, and space. It is, however, a good indicator for moist soils, because some species have underground rhizomes, runners, and/or stolons [26], but is a known problem weed across many agro-ecologies of southern Africa once it establishes. Halvorson and Guertin (2003) [27] suggested the presence of allelopathic properties in $C$. dactylon, where poor competitors are phased out within a short space of time; this could explain its dominance. 


\subsection{Mulching Suppressed Weed Density and Diversity}

Mulching appeared to suppress weeds, resulting in low overall biomass (Table 4). The mulching effect on weed suppression was more pronounced in the ripping and planting basin options. Under some fertilization treatments such as cowpea-maize and maize-cowpea rotations subjected to low fertilizer rates, mulching suppressed the weed emergence by between $40 \%$ and $60 \%$ (Figure 3 ). This is in contrast to findings by Mashingaidze et al. (2012) [28] who, working with sorghum and cowpea, found that mulching significantly increased weed density, as a result of probable improvements in the soil micro-environment. At Domboshawa, however, while similar processes may have promoted weed seed germination, mulch most likely smothered the germinated seedlings across the treatments, such that at quantification, only surviving individuals were accounted for. Another reason for lower seed populations under mulch could be due to seed-rot linked to excessive soil moisture experienced during the early part of both seasons. Flash floods were experienced during the months of December and January in 2011-2014, leading to excessive water logging, particularly under the basin option.

Differences in species diversity were also apparent in mulched versus no-mulch treatments. For example, regardless of fertility treatments, a Shannon-Wiener diversity index of 2.1 was measured for basins under mulch versus 2.8 for basins where no mulch was applied (Figure 4), although the same herbaceous annual, G. parviflora, continued to dominate. The same trends were observed for the ripping option. Under conventional tillage, while mulching appeared not to have significantly influenced $(p<0.05)$ weed diversity (mean 2.5), species richness was lower under mulched plots (4-7 species) compared to unmulched plots (6-13).

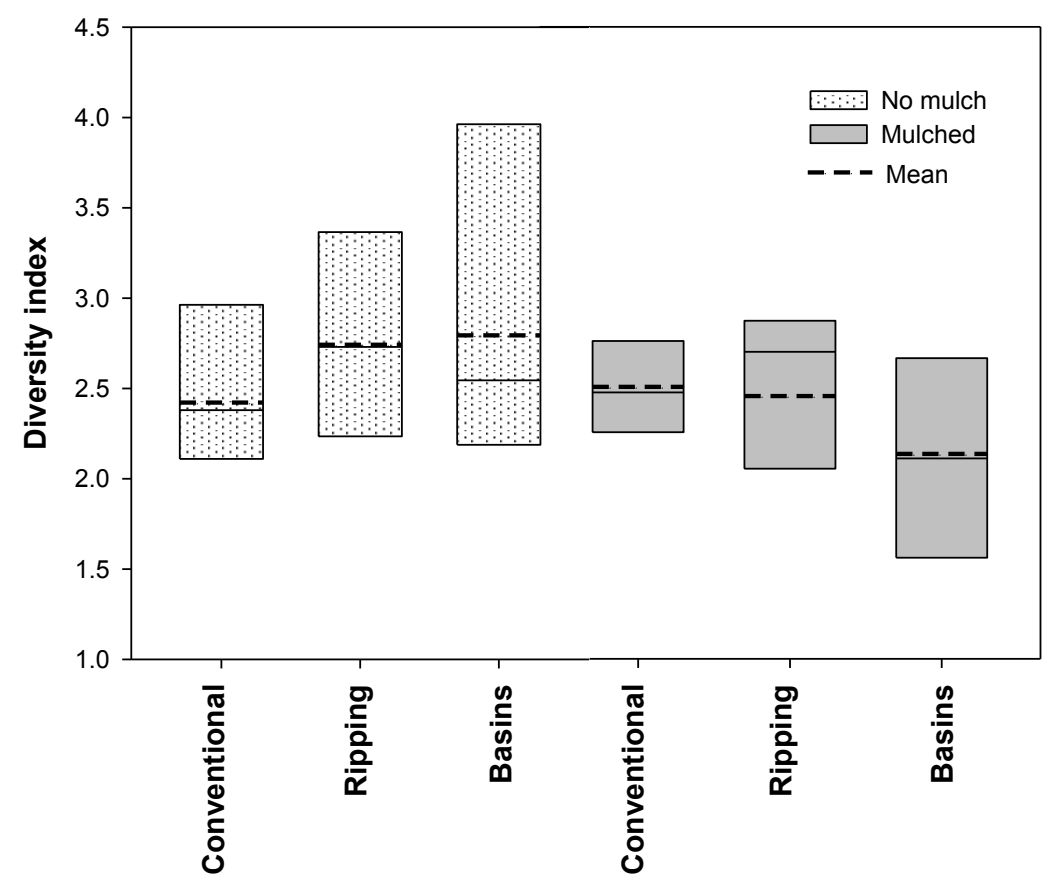

Crop Establishment Option

Figure 4. Shannon-Wiener diversity indices of weeds under mulch and no-mulch treatments on three tillage options in Domboshawa, Zimbabwe. 
Table 4. Short-term effects of different soil fertility treatments on weed biomass under mulched and no-mulch conditions.

\begin{tabular}{|c|c|c|c|c|c|}
\hline & \multirow[t]{2}{*}{ Season 1 Treatments } & & \multirow[t]{2}{*}{ Season 2 Treatments } & \multicolumn{2}{|c|}{$\begin{array}{c}\text { Weed Biomass Season } \\
2 \\
\left(\mathrm{~g} \cdot \mathbf{m}^{-2}\right) \\
\end{array}$} \\
\hline & & & & Mulch & No Mulch \\
\hline 2. & Fertilized cowpea $(17 \mathrm{~kg} \cdot \mathrm{N} ; 26 \mathrm{~kg} \cdot \mathrm{P})$ & 2. & Fertilized maize $(120 \mathrm{~kg} \cdot \mathrm{N} ; 26 \mathrm{~kg} \cdot \mathrm{P})$ & $344(28)^{b}$ & $456(41)^{\mathrm{e}}$ \\
\hline 3. & Fertilized maize $(35 \mathrm{~kg} \cdot \mathrm{N} ; 14 \mathrm{~kg} \cdot \mathrm{P})$ & 3. & Fertilized cowpea $(8 \mathrm{~kg} \cdot \mathrm{N} ; 14 \mathrm{~kg} \cdot \mathrm{P})$ & $77(23)^{c}$ & $133(38)^{\mathrm{c}}$ \\
\hline 4. & Fertilized cowpea $(8 \mathrm{~kg} \cdot \mathrm{N} ; 14 \mathrm{~kg} \cdot \mathrm{P})$ & 4. & Fertilized maize $(35 \mathrm{~kg} \cdot \mathrm{N} ; 14 \mathrm{~kg} \cdot \mathrm{P})$ & $118(51)^{\mathrm{c}}$ & $201(59)^{a, d}$ \\
\hline 7. & Unfertilized maize-(Control) & 7. & Unfertilized maize-(Control) & $96(20)^{\mathrm{c}}$ & $122(42)^{\mathrm{c}}$ \\
\hline 8. & Fertilized maize - $(120 \mathrm{~kg} \cdot \mathrm{N} ; 26 \mathrm{~kg} \cdot \mathrm{P})$ & 8. & Fertilized maize $-(120 \mathrm{~kg} \cdot \mathrm{N} ; 26 \mathrm{~kg} \cdot \mathrm{P})$ & $191(31)^{\mathrm{a}, \mathrm{d}}$ & $258(69)^{a, d}$ \\
\hline \multicolumn{4}{|c|}{ SED } & 43.6 & 55.1 \\
\hline
\end{tabular}

Figures in brackets indicate standard deviation, while means followed with the same letter (a,b,c,d or e) within and across treatments are not significantly different. 


\subsection{Implications of Mulching for Smallholder Farmers}

Weeds in arable lands are high consumers of water and nutrients, and are therefore capable of reducing the availability of these resources essential for crop growth. Hoeing is the most prevalent method of weed control on smallholder farms. Several studies have shown the yield gaps of high magnitudes, $>50 \%$, on early weeded versus fields where weeding was delayed by about six weeks after crop emergence, and over $90 \%$ where no weeding was conducted at all $[6,7,29]$. The reported decrease in yields can mostly be attributed to the superiority of weeds in competing for production resources compared to most field crops. Studies by Marais (1983) [29] also indicated that field production was proportional to the amount of dry matter produced by the weeds, confirming the relationship between background fertility and weed biomass productivity. The data imply that weed proliferation under mulch may be a question of background fertility rather than enhanced soil moisture availability alone. On inherently low-fertility soils such as those found at Domboshawa, weed diversity, dominance, and biomass are less likely to vary due to tillage, at least in the short term.

While cattle manure is a beneficial soil amendment, its application is associated weed infestation, a feature of which most farmers are aware. The major source of these weed seeds is the rangelands, where livestock freely graze on diverse pastures, a common feature in smallholder communities in Zimbabwe. Partially digested plant materials including whole seeds are a common characteristic of cow dung. However, studies have shown that pre-treating manure, e.g., by heaping or compositing in pits, before field application has been found to address the weed seed problems by reducing their viability [30]. Such treatment processes are known to generate high temperatures within the manure heap or pit, often accompanied by the release of toxic gases that kill weed seeds [25].

Although fertilization increased the growth of the weeds, this was apparently moderated under mulching. The degree of soil cover by mulch or cover crops should also be critically considered for meaningful impact. In this study, a mulch cover of $30 \%$ with maize stover was enough to impact marginally on weed performance, but the results indicated that some weeding was still necessary. Generating the required biomass for mulching purposes has often remained a challenge on inherently poor soils [31,32], to the extent that farmers fail to generate the required mulching materials. The potential savings in terms of costs of herbicides or labor required for weeding, as well as time spent on weeding, cannot be underestimated. Some estimates suggest labor savings of up to $50 \%$, if weeding were to be eliminated [33]. It is therefore proposed that, given the competing uses of maize stover on farms for livestock feed, farmers could use alternative mulching materials such as veld grasses, woodland litter, or cover-crops within their cropping cycles. Such strategies would not only address the weed problem, but also fertility and soil moisture conservation given the high variability in rainfall patterns in recent years. While results from the Domboshawa study indicated that legume-cereal rotations promoted weed growth, at least in the short term, as the soil environment was enriched by the legumes, such practices have been known to reduce some problem weeds and pests [6,11]. Rotations coupled with mulching will likely bring about a desired result and reduce weed growth. 


\section{Conclusions}

Weed dynamics was primarily influenced by fertilization, mulching and to a lesser extent, crop establishment method. High fertilization rates of $>90 \mathrm{~kg} \cdot \mathrm{N} \cdot \mathrm{ha}^{-1}, 26 \mathrm{~kg} \cdot \mathrm{P} \cdot \mathrm{ha}^{-1}, 4-7 \mathrm{t}$ manure $\cdot \mathrm{ha}^{-1}$ and the residual effects of a nitrogen-fixing leguminous crop such as cowpea promote weed growth and diversity. However, mulching at a minimum rate of at least $30 \%$ soil cover could effectively contribute to significant weed reduction even under high fertilization rates on both conventional and CA systems. The grass species E. indica and Cynodon spp. and the dicots Amaranthus thunbergii and Acanthospermum hispidum were associated with cattle manure application, and apart from A. thunbergii, weeds can also thrive in poor fertility conditions. Maize stover mulching and cowpea-maize rotations probably contributed to the lack of significant differences in weed species composition and diversity among conventional, ripping, and planting basin options. Access to mulching materials would save labor costs associated with weeding under smallholder management. There is, however, a need to conduct more studies on weed population dynamics under candidate mulching materials accessible to farmers, including woodland litter and different grass types. In addition, weed dynamics under mulching during the middle to end of the season and their impact on crop productivity in maize systems remain largely unknown.

\section{Acknowledgments}

The authors acknowledge funding from the European Union through the lead organization, African Conservation Tillage Network (ACT) of Nairobi, Kenya, grant No. Europe Aid/138500/C/ACT/Multi) for the Agroecology-Based Aggradation-Conservation Agriculture: Tailoring Innovations to Combat Food Insecurity in Semi-Arid Africa (ABACO) Project to the Soil Fertility Consortium of Southern Africa (SOFECSA) hosted by the University of Zimbabwe.

\section{Author Contributions}

Paul Mapfumo had the original idea for the study, and together with the lead author, Florence Mtambanengwe, supervised the research work under SOFECSA, and was responsible for revising the manuscript. Hatirarami Nezomba, Tonny Tauro, Muneta G. Manzeke, and Christopher Chagumaira were responsible for data collection and analysis, and revision of final manuscript.

\section{Conflicts of Interest}

The authors declare no conflict of interest.

\section{References}

1. Mazvimavi, K; Twomlow, S. Socioeconomic and institutional factors influencing adoption of conservation farming by vulnerable households in Zimbabwe. Agric. Syst. 2009, 101, 20-29.

2. Thierfelder, C.; Wall, P.C. Effects of conservation agriculture techniques on infiltration and soil water content in Zambia and Zimbabwe. Soil Tillage Res. 2009, 105, 217-227. 
3. Mupangwa, W.; Twomlow, S.; Walker, S. Reduced tillage, mulching and rotational effects on maize (Zea. mays L.), cowpea (Vigna. unguiculata (Walp) L.) and sorghum (Sorghum bicolor L. (Moench)) yields under semi-arid conditions. Field Crop. Res.2012, 132, 139-148.

4. FAO. Weed Control in Smallholder Conservation Agriculture, 2012. Available online: http://www.fao.org/ca/Training_materials/leaflet/weedcontrol.pdf(accessed on 20 July 2015).

5. Chuma, E.; Mombeshora, B.G.; Murwira, H.K.; Chikuvire, J. The dynamics of soil fertility management in Zimbabwe. In Nutrients on the Move. Soil Fertility Dynamics in African Farming Systems; Hilhorst, T., Muchena, F., Eds.; International Institute for Environment and Development: London, UK, 2000; pp. 45-64.

6. Mashingaidze, A.B. Improving Weed Management and Crop Productivity in Maize Systems in Zimbabwe. Ph.D. Thesis, Wageningen University, Wageningen, The Netherlands, 2004; p. 196.

7. Nyamangara, J.; Mashingaidze, N.; Masvaya, E.N.; Nyengerai, K.; Kunzekweguta, M.; Tirivavi, R.; Mazvimavi, K. Weed growth and labor demand under hand-hoe based reduced tillage in smallholder farmers' fields in Zimbabwe. Agric. Ecosyst. Environ. 2014, 187, 146-154.

8. Mapfumo, P.; Mtambanengwe, F.; Nezomba, H.; Manzeke, M.G. Options for adaptation of conservation Agriculture practices on nutrient-depleted soils by smallholder farmers in southern Africa. In 1st ACCA Africa Congress on Conservation Agriculture. Book of Condensed Papers; ACT/NORAD: Nairobi, Kenya, 2014; pp. 118-120.

9. Ndah, H.T.; Schuler, J.; Uthes, S.; Zander, P.; Traore, K.; Gama, M.S.; Nyagumbo, I.; Triomphe, B.; Sieber, S; Corbeels, M. Adoption Potential of Conservation Agriculture Practices in Sub-Saharan Africa: Results from Five Case Studies. Environ. Manag. 2014, 53, 620-635.

10. Kombiok, J.M.; Alhassan, A.Y. Tillage effects on subsequent weed types, population and biomass in maize cropped in Northern Savanna zone of Ghana. J. Sustain. Agric. 2007, 30, 47-57.

11. Mashingaidze, N. Weed Dynamics in Low-Input Dryland Smallholder Conservation Agriculture Systems in Semi-Arid Zimbabwe. Ph.D. Thesis, University of Pretoria, Pretoria, South Africa, 2013; p. 188.

12. Mashingaidze, N.; Madakadze, I.C.; Twomlow, S.J. Response of weeds and maize to planting basin tillage in semi-arid Zimbabwe. In Proceedings of the African Crop Science Conference, Cape Town, South Africa, 28 September-2 October 2009; pp. 259-261.

13. FAO Document Repository. Hot Pepper Seed and Crop Production in the Bahamas. Mulching. Available online: http://www.fao.org/docrep/007/y5259e/y5259e09.htm\# (accessed on 13 January 2014).

14. Vincent, V.; Thomas, R.G. An Agroecological Survey of Southern Rhodesia: Part 1-Agro-Ecological Survey; Government Printer: Salisbury, Rhodesia, 1961.

15. World Reference Base for Soils, FAO/ISRIC/ISSS. World Soil Resources Report No. 84; Food and Agriculture Organization: Rome, Italy, 1998.

16. Tittonell, P.; Scopel, E.; Andrieu, N.; Posthumus, H.; Mapfumo, P.; Corbeels, M.; van Halsemaf, G.E.; Lahmar, R.; Lugandu, S.; Rakotoriosa, J.; et al. Agroecology-based aggradation-conservation agriculture (ABACO): Targeting innovations to combat soil degradation and food insecurity in semi-arid Africa. Field Crop. Res. 2012, 132, 168-174.

17. Weaver, J.E. The Quadrat Method in Teaching Ecology. Plant World 1918, 21, 267-283. 
18. Wheater, C.P.; Bell, J.R.; Cook, P.A. Practical Field Ecology: Project Guide; John Wiley and Sons: Chichester, UK, 2011.

19. Gomez, K.A.; Gomez, A.A. Statistical Procedures for Agricultural Research, 2nd ed.; John Wiley \& Sons: New York, NY, USA, 1984; p. 680.

20. VSN. GenStat for Windows, 14th ed.; VSN International: Hempstead, UK, 2011.

21. Shannon, C.E. A mathematical theory of communication. The Bell Syst. Tech. J. 1948, 27, 379-423.

22. Chivinge, O.A. Weed science technological needs for communal areas of Zimbabwe. Zambezia 1990, 17, 133-143.

23. Munguri, W.M; Mariga, I.K; Chivinge, O.A. Optimising cattle manure utilisation in Chinyika Resettlement Area, Zimbabwe. In Proceedings of the International Crop Science Conference for East and Southern Africa, Blantyre, Malawi, 19-24 February 1995.

24. Pleasant, J.M.; Schlather, K.J. Incidence of weed seed in cow manure and its importance as weed source for cropland. Weed Technol. 2000, 8, 304-310.

25. Rupende, E.; Chivinge, O.A.; Mariga, I.K. The effect of curing cattle manure on survival of weed seeds and nutrient release. In Proceedings of the biennial weed science conference of East Africa, Morogoro, Tanzania, 18-22 September 1995.

26. Van Oudtshoorn, F. Guide to Grasses of Southern Africa; Briza Publications: Cape Town, South Africa, 2002; pp. 228-228.

27. Halvorson W.L.; Guertin, P. USGS Weed in the West Project: Status of Introduced Plants in Southern Arizona Parks. Factsheet for: Cynodon. dactylon (L.) Pers.; US Geological Survey: Tucson, AZ, USA, 2003; p. 12.

28. Mashingaidze, N.; Madakadze, I.C.; Twomlow, S. Response of weed flora to conservation agriculture systems and weeding intensity in semi-arid Zimbabwe. Afr. J. Agric. Res. 2012, 7 , 5069-5082.

29. Marais, J.N. Weed Competition in Maize with Reference to Peasant Farming. Fort Hare Papers, University of Fort Hare, Alice, South Africa, 1983; pp. 72 and 208.

30. Nzuma, J.K. Manure management options for increasing crop production in the smallholder sectors of Zimbabwe. Ph.D. Thesis, University of Zimbabwe, Harare, Zimbabwe, 2002.

31. Mtambanengwe, F.; Mapfumo, P. Combating food insecurity on sandy soils in Zimbabwe: The legume challenge. Symbiosis 2009, 48, 25-36.

32. Nezomba, H.; Mtambanengwe, F.; Tittonell, P.; Mapfumo, P. Point of no return? Rehabilitating degraded soils for increased crop productivity on smallholder farms in eastern Zimbabwe. Geoderma 2015, 239, 143-155.

33. FAO. The Economics of Conservation Agriculture. Available online: ftp://ftp.fao.org/agl/agll/docs/ ecconsagr.pdf. (accessed on 21 July 2014).

(C) 2015 by the authors; licensee MDPI, Basel, Switzerland. This article is an open access article distributed under the terms and conditions of the Creative Commons Attribution license (http://creativecommons.org/licenses/by/4.0/). 